\title{
Economic Security of Enterprises in the Conditions of Digital Technologies and Pandemic
}

The article is devoted to solving scientific problems of economic security of economic entities of various forms of ownership, in particular in the conditions of digital technologies and pandemics. The essence of "economic security of the enterprise" is defined, the review of leading scientists-economists concerning the specified research topic is made. The significance of economic security of enterprises is substantiated, the ways of solving problems in activity of enterprises are offered.

Based on the analysis of the publications of scientists, we have identified in the classical form: international, state, regional, sectoral, private or economic level of economic security. In our opinion, the economic security of any enterprise is an opportunity to carry out activities, maintain normal working conditions, development, and in cases of external and internal challenges, threats, risks, dangers to resist and resume their activities.

Among the proposals to strengthen the economic security of each enterprise, we recommend: diversification and expansion of production, which will increase economic efficiency, namely the profitability of the enterprise, the range and additionally attract existing employees; reduce operating costs by optimizing online and offline operation, implementation of energy savings - day and night, etc; introduction of aggressive marketing, namely increase of net income due to occupation of new market segments; introduction of investment attractiveness of the enterprise, introduction of new technologies, creation of more qualitative production; input quality control of raw materials, control over technological operations, development of control system and quality assessment for individual technological operations - search for analogues; participation in exhibitions, presentations at various levels; constant monitoring and adjustment of data; conducting promotional discounts and attracting new potential consumers of the company's products.

economic security, digital technologies, enterprise, pandemic, business

Одержано (Received) 16.10.2020

Прорецензовано (Reviewed) 27.10.2020

Прийнято до друку (Approved) 21.12.2020

УДК 330.341.2

JEL Classification: 025

DOI: https://doi.org/10.32515/2663-1636.2020.5(38).176-181

Л.о. Жилінська, доц., д-р екон. наук

Дніпровський національний університет залізничного транспорту ім. академіка В. Лазаряна, м. Дніпро, Україна

\section{Пріоритетні напрями стимулювання розвитку промисловості у містах, які перебувають на постконфліктних територіях}

Стаття присвячена аналізу та пошуку пріоритетних напрямів стимулювання розвитку промислових підприємств, які знаходяться на постконфліктних територіях. Представлено трактування терміну «постконфліктні території». Проведено аналіз промислової галузі Донецької та Луганської областей та виявлено причини падіння обсягів реалізації промислової продукції. Охарактеризовано провідні підприємства промислового сектору Донецької та Луганської областей, які знаходяться на території підконтрольної української владі. Проведено аналіз напрямів для стимулювання промислового сектору української економіки. Визначено пріоритетні напрями стимулювання розвитку промисловості у містах, які перебувають на постконфліктних територіях.

розвиток, постконфліктні території, промислові підприємства, управління, трансформація

Л.А. Жилинская, доц., д-р. экон. наук

Днепровский национальный университет железнодорожного транспорта им. академика В.Лазаряна, г. Днепр, Украина

Приоритетные направления стимулирования развития промышленности в городах, которые находятся на постконфликтных территориях

(с) Л.О. Жилінська, 2020 
Статья посвящена анализу и поиску приоритетных направлений стимулирования развития промышленных предприятий, которые находятся на постконфликтных территориях. Представлена трактовка термина «постконфликтные территории». Проведен анализ промышленной отрасли Донецкой и Луганской областей на основании чего выявлены причины падения объемов реализации промышленной продукции. Охарактеризованы ведущие предприятия промышленного сектора Донецкой и Луганской областей, которые находятся на территории подконтрольной украинской власти. Проведен анализ направлений для стимулирования промышленного сектора украинской экономики. Определены приоритетные направления стимулирования развития промышленности в городах, находящихся на постконфликтных территориях.

развитие, постконфликтные территории, промышленные предприятия, управление, трансформация

Постановка проблеми. В умовах бойових дій та зміни геополітичних реалій на сході України особливої актуальності набувають питання пошуку пріоритетних напрямів стимулювання розвитку промислового сектору економіки, від якого залежить соціально-економічна стабільність в регіоні. Відродження Донбасу та підвищення конкурентоспроможності промислових підприємств регіону виступає нагальною необхідністю та потребує адекватної державної уваги і підтримки для подолання наслідків збройного конфлікту.

На сьогодні процеси реалізації заходів для відновлення міст, які перебувають на постконфліктних територіях, здійснюється на засадах старої промислової політики, що негативно впливає на промисловий та економічний потенціал країни в цілому. Питання структурних змін в промисловості залишаються нерозв'язаними та дискусійними, що визначає необхідність формування нових інструментів, механізмів, стабілізаційних заходів для реалізації трансформаційних процесів розвитку. Тому пріоритетними на сьогоднішній день $є$ питання розробки напрямів для гармонізації, структурної перебудови, стимулювання стратегічного розвитку промислового сектору економіки міст, які перебувають на постконфліктних територіях.

Аналіз останніх досліджень і публікацій. Проблеми пошуку напрямів для стимулювання промислового сектору української економіки знайшли своє відображення у працях багатьох науковців. Так, Інститутом економіко-правових досліджень НАН України спільно з Фондом імені Фрідріха Еберта (Німеччина) та Асоціацією вчених-внутрішньо переміщених осіб [2] проведено дослідження стану економіко-правового забезпечення та запропоновані шляхи сталого розвитку Донбасу з метою підвищення інвестиційної привабливості економіки східних регіонів України. Авторським колективом за редакцією док. екон. наук Дейнеко Л.В. [4] проведено оцінку перспектив розвитку, запропоновано шляхи модернізації виробничого потенціалу, обгрунтовано напрями та механізми сприяння інтеграції України в глобальний ринок. Авторським колективом Інституту економіки та прогнозування НАН України [7] розглянуто структурні трансформації промислового сектору та його вплив на економічний розвиток України.

Аналіз наукових праць, авторів науково-аналітичної доповіді та монографії, свідчить, що доки не сформовано цілісного і системного уявлення про напрями необхідних трансформацій промислового сектору. Тому існує об'єктивна необхідність та потребує більш поглибленого дослідження вивчення пріоритетних напрямів стимулювання розвитку промисловості у містах, які перебувають на постконфліктних територіях.

Постановка завдання. Метою статті $є$ дослідження пріоритетних напрямів стимулювання розвитку промисловості у містах, які перебувають на постконфліктних територіях. 
Виклад основного матеріалу. Термін «постконфліктні території» на даному етапі не висвітлено у нормативно-правовій базі України. Провідними вченими Інституту економіко-правових досліджень ім. В.К. Мамутова НАНУ в праці [8] запропоновано закріпити у Законі України від 21.06.2018 № 2469-VIII «Про національну безпеку України» наступне трактування цього поняття «зазначена частина території України, що зазнала негативного впливу внаслідок збройного конфлікту, яка перебуває під юрисдикцією України та потребує здійснення заходів із відновлення функціонування об'єктів життєдіяльності та виробничої сфери [8].

32014 року триває збройний конфлікт на територіях Донецької та Луганської областей. Наслідком є окупація частин регіону: Донецька область - 446 населені пункти, 60\% виробничого потенціалу; Луганська область - 75\% промислового потенціалу, 25 міст, 81 селищ міського типу та 263 сільських населених пунктів $[5,6]$.

Донецька та Луганська області найбільші в Україні за своїм промисловим потенціалом. За даними Державної служби статистики [1] у 2012 році обсяги реалізованої промислової продукції (товарів, послуг) Донецької області у \% співвідношенні з 24 регіонами та м. Київ складала 20\%, Луганської області 7,3\%. Порівняно з 2019 роком ці показники зменшились до 11,4\% та 0,88\% відповідно. Обсяги промислового виробництва скоротилися майже на $30 \%$. Порівняння показників розвитку промисловості Донбасу з показниками областей України впали на 50\%.

Причинами падіння обсягів реалізації $є$ : збройний конфлікт на територіях зазначених областей; позбавлення в результаті окупації наступних галузей промисловості: металургія, виробництво коксу, продуктів нафтопереробки, машинобудування; зупинка промислових підприємств; скорочення завантаження промислових потужностей; обмеження в постачанні сировини 3 непідконтрольних територій; логістичні обмеження; пошкодження автомобільних, залізничних доріг, ліній електропередач, газопроводів; втрата контролю над вугільними шахтами (понад 60\%); відсутність антидепінгових програм для ввезення дешевої сировини; високі ціни на газ в результаті чого висока собівартість продукції та ііі неконкурентоспроможність на ринках; відсутність державних програм фінансування на технологічні новації та переоснащення.

Провідними підприємствами промислового сектору Донецької області, які знаходяться на території підконтрольної української владі є [5]:

металургійні підприємства: ПрАТ «Металургійний комбінат «Азовсталь», ПрАТ «Маріупольський металургійний комбінат ім. Ілліча», ТОВ «Краматорський феросплавний завод», ТОВ «Завод по обробці кольорових металів», ТОВ «Електросталь»;

коксохімічні підприємства: ПрАТ «Металургійний комбінат «Азовсталь», ПрАТ «Авдіївський коксохімічний завод; вогнетривкі підприємства: ПАТ «КДЗ», ПрАТ «Великоанадольський вогнетривкий комбінат», ПАТ «Часівоярський вогнетривкий комбінат», ПрАТ «Красногорівський вогнетривкий завод»;

- підприємство по виробництву флюсів: ПрАТ «Новотроїцьке рудоуправління».

Основні промислові підприємства, які знаходяться в Луганської області на території підконтрольної української владі [6], зосереджено в містах Сєверодонецьк, Рубіжне, Лисичанськ та Кремінна.

На сьогодні в Україні затверджено Державну стратегію регіонального розвитку на 2021-2027 роки [3], де висвітлено основні тенденції та проблеми, які стримують 
розвиток регіонів, надано стратегічну мету, пріоритети, інструменти та завдання регіонального розвитку.

Авторами монографії [2] запропоновано наступні напрями для стимулювання та розвитку промисловості у містах, які знаходяться на постконфліктних територіях: впровадження спеціального режиму господарювання; стимулювання реалізації інвестиційних проектів; використання потенціалу сектору наукоємних та високотехнологічних підприємств; затвердження довгострокової державної цільової програми модернізації та розвитку промислового сектору; впровадження системи стимулів для промислових підприємств; впровадження енергоефективних та ресурсозберігаючих технологій; активізувати концепцію SMART-спеціалізації; впровадити «освіту сталого розвитку».

Кіндзерський Ю.В. [7] під основними напрямами розвитку промисловості вважає: модернізацію та підвищення технологічного рівня виробництва; розвиток переробних виробництв; замикання технологічних ланцюгів створення нової доданої вартості; перегляд промислової політики; активізація інвестиційної та інноваційної діяльності; перегляд зовнішньої політики для захисту виробників від експансії імпорту; активізація внутрішнього підприємництва.

Аналіз праць [2; 3; 4; 5; 6; 7] дає змогу визначити пріоритетні напрями стимулювання розвитку промисловості у містах, які перебувають на постконфліктних територіях:

1. Визначити стратегічні орієнтири, ресурси та можливості для створення умов підвищення інвестиційної привабливості промислових підприємств, які знаходяться на постконфліктних територіях через інституціональну підтримку (державний бюджет, державні замовлення, гранти, венчурні фонди, комерційні банки).

2. Формування нової економічної парадигми управління промисловими підприємствами, заснованої на концепції індустріальних кластерів.

3. Забезпечення взаємодії промислових підприємств 3 науково-дослідними інститутами, що надасть можливість обміну науковими досягненнями та спільне проведення НДДКР у розвиток виробничої, комунікаційної, транспортної та соціальної інфраструктури постконфліктних територій.

4. Залучення підприємницьких структур для відновлення об'єктів, які постраждали у результаті збройного конфлікту.

5. Запровадження ринкових теорій транснаціоналізації виробництва для підвищення конкурентоспроможності промислових підприємств Донецької та Луганської областей.

6. Запустити трансформаційні процеси в економічної діяльності промислових підприємств шляхом перепроектування бізнес-процесів, впровадження нових моделей в управління господарською діяльністю.

7. Перетворення інтелектуального та людського ресурсу в головний актив підприємства.

8. Створення інноваційного сектору досліджень та розробок для модернізації виробничих процесів промислових підприємств.

9. Забезпечення зниження податкових ставок на період трансформаційних процесів у виробництві для мінімізації собівартості виготовленої продукції та підвищення конкурентоспроможності промислових підприємств Донецької та Луганської областей на міжнародних ринках.

Висновки та перспективи подальших досліджень В результаті дослідження пріоритетних напрямів стимулювання розвитку промисловості у містах, які перебувають на постконфліктних територіях Донецької та Луганської областей, можна 
зробити висновки, що стратегія розвитку має бути спрямована на модернізацію виробництва, інноваційних розробок, переорієнтацію економічної та господарської діяльності промислових підприємств, підвищення інвестиційної привабливості регіону, на рівні держави - удосконалення законодавчих та податкових механізмів управління, розробки загальних стратегій розвитку територій та об’єктів промислового виробництва.

У подальших дослідженнях слід зосередити увагу на удосконаленні методологічних підходів до формування нової економічної парадигми управління промисловими підприємствами у містах, які перебувають на постконфліктних територіях.

\section{Список літератури}

1. Державна служба статистики України. URL: http://www.ukrstat.gov.ua/(дата звернення: 07.09.2020).

2. Економіко-правові засоби стимулюючого впливу на розвиток Донбасу: монографія / під заг. ред. В.А. Устименка. Київ : НАН України, Інститут економіко-правових досліджень, 2019. 236 с.

3. Постанова Кабінету Міністрів України «Про затвердження Державної стратегії регіонального розвитку на 2021-2027 роки» від 05 серпня 2020 року №695. Урядовий портал. URL: https://www.kmu.gov.ua/npas/pro-zatverdzhennya-derzhavnoyi-strategiyi-regionalnogo-rozvitku-na20212027-t50820/(дата звернення: 09.09.2020).

4. Розвиток промисловості для забезпечення зростання та оновлення української економіки : науково-аналітична доповідь / за ред. д-ра екон. наук Дейнеко Л.В. ; НАН України, ДУ «Ін-т екон. та прогнозув. НАН України». К., 2018. 158 с.

5. Стратегія розвитку Донецької області на період до 2027 року: затв. розпорядженням голови облдержадміністрації, керівника обласної військово-цивільної адміністрації від 17.02.2020 № 147/5-20. Офіційний сайт Донецької обласної державної адміністрації. URL: https://dn.gov.ua/ua/projects/strategiya-rozvitku-doneckoyioblasti-na-period-do-2027-roku ） (дата звернення: 10.09.2020).

6. Стратегія розвитку Луганської області на період на 2021-2027 роки: затв. розпорядженням голови облдержадміністрації, керівника обласної військово-цивільної адміністрації від 26.03.2020 № 246. URL: https:// http://loga.gov.ua/sites/default/files/collections/strategiya_lugansk_2027_last.pdf (дата звернення: 10.09.2020)

7. Структурні трансформації в економіці України: динаміка, суперечності та вплив на економічний розвиток: наукова доповідь: науково-аналітична доповідь / за ред. д-ра екон. наук Щинкарук Л.В.; НАН України, ДУ «Ін-т екон. та прогнозув. НАН України». К., 2015. 303 с.

8. Устименко В.А., Джабраілов Р.А. Економічна безпека постконфліктних територій: деякі аспекти правового забезпечення. Економіка та право. 2020. № 2. С. 3-13.

\section{References}

1. Derzhavna sluzhba statystyky Ukrainy [State Statistics Service of Ukraine]. ukrstat.gov.ua. Retrieved from http://www.ukrstat.gov.ua [in Ukrainian].

2. Ustymenka, V.A. (Eds.). (2019). Economic and legal means of stimulating the development of Donbass. Kyiv : NAN Ukrainy, Instytut ekonomiko-pravovykh doslidzhen.

3. Postanova Kabinetu Ministriv Ukrainy «Pro zatverdzhennia Derzhavnoi stratehii rehionalnoho rozvytku na 2021-2027 roky» vid 05 serpnia 2020 roku №695. Uriadovyi portal. [Resolution of the Cabinet of Ministers of Ukraine "On approval of the State Strategy for Regional Development for 2021-2027" of August 5, 2020 №695. Government portal]. kmu.gov.ua. Retrieved from https://www.kmu.gov.ua/npas/pro-zatverdzhennya-derzhavnoyi-strategiyi-regionalnogo-rozvitku-na20212027-t50820[in Ukrainian].

4. Deineko, L.V. (2018). Rozvytok promyslovosti dlia zabezpechennia zrostannia ta onovlennia ukrainskoi ekonomiky [Development of industry to ensure the growth and renewal of the Ukrainian economy]. Kyiv : NAN Ukrainy, DU «In-t ekon. ta prohnozuv. NAN Ukrainy» [in Ukrainian].

5. Stratehiia rozvytku Donetskoi oblasti na period do 2027 roku: zatv. rozporiadzhenniam holovy oblderzhadministratsii, kerivnyka oblasnoi viiskovo-tsyvilnoi administratsii vid 17.02.2020 № 147/5-20. Ofitsiinyi sait Donetskoi oblasnoi derzhavnoi administratsii [Development strategy of Donetsk region for 
the period up to 2027: approved. by order of the head of the regional state administration, the head of the regional military-civil administration from 17.02.2020 № 147 / 5-20. Official site of Donetsk regional state administration] dn.gov.ua/ua. Retrieved from https://n.gov.ua/ua/projects/strategiya-rozvitkudoneckoyioblasti-na-period-do-2027-roku [in Ukrainian].

6. Stratehiia rozvytku Luhanskoi oblasti na period na 2021-2027 roky: zatv. rozporiadzhenniam holovy oblderzhadministratsii, kerivnyka oblasnoi viiskovo-tsyvilnoi administratsii vid 26.03 .2020 № 246 [Development strategy of Luhansk region for the period for 2021-2027: approved. by order of the head of the regional state administration, the head of the regional military-civil administration from 03/26/2020 № 246]. loga.gov.ua. Retrieved from https:// http://loga.gov.ua/sites/default/files/collections/strategiya_lugansk_2027_last.pdf [in Ukrainian].

7. Shchynkaruk, L.V (2015) Strukturni transformatsii v ekonomitsi Ukrainy: dynamika, superechnosti ta vplyv na ekonomichnyi rozvytok [Structural transformations in the economy of Ukraine: dynamics, contradictions and impact on economic development]. Kyiv : NAN Ukrainy, DU «In-t ekon. ta prohnozuv. NAN Ukrainy» [in Ukrainian].

8. Ustymenko, V.A., \& Dzhabrailov, R.A. (2020) Ekonomichna bezpeka postkonfliktnykh terytorii: deiaki aspekty pravovoho zabezpechennia [Economic security of post-conflict areas: some aspects of legal support]. Ekonomika ta pravo - Economics and law, 2, 3-13 [in Ukrainian].

Ludmila Zhylinska, Associate Professor, Doctor of Economics (Doctor of Economic Sciences) Dnipropetrovsk National University of Railway Transport named after Academician V. Lazaryan, Dnipro, Ukraine

\section{Priority Areas for Stimulating Industrial Development in Cities Located in Post-conflict} Areas

The purpose of the article is to study the priority areas of stimulating the development of industry in cities in post-conflict areas. Today, the processes of implementing measures to rebuild cities in post-conflict territories are carried out on the basis of the old industrial policy, which negatively affects the industrial and economic potential of the country as a whole. The issues of structural changes in industry remain unresolved and controversial, which determines the need for the formation of new tools, mechanisms, stabilization measures for the implementation of transformational development processes. Therefore, the priority today is the issue of developing directions for harmonization, restructuring, stimulating the strategic development of the industrial sector of the economy of cities in post-conflict territories.

The article presents the interpretation of the term "post-conflict territories". The analysis of the industrial sector of Donetsk and Lugansk regions was carried out, on the basis of which the reasons for the fall in the volume of sales of industrial products were identified. The leading enterprises of the industrial sector of the Donetsk and Lugansk regions, which are located on the territory controlled by the Ukrainian government, are presented. The analysis of directions for stimulating the industrial sector of the Ukrainian economy is carried out. The priority directions of stimulating the development of industry in cities located in post-conflict territories have been determined.

As a result of the study of priority areas for stimulating the development of industry in cities located in the post-conflict territories of Donetsk and Lugansk regions, it can be concluded that the development strategy should be implemented through the modernization of production, innovative developments, reorientation of the economic and economic activities of industrial enterprises, increasing the investment attractiveness of the region, at the level states - improving legislative and tax management mechanisms, developing general strategies for the development of territories and industrial facilities.

development, post-conflict areas, industrial enterprises, governance, transformation 